Jusual de Juse

Volume 12 Nomor 2, 1 Oktober 2020

ISSN (Print): 2085-8477; ISSN (Online): 2655-4348

\title{
Penggunaan Certified Emission Reductions Sebagai Bukti Objek Transaksi Carbon Crediting
}

\section{Use of Certified Emission Reductions as Evidance Carbon Crediting Transaction Object}

\author{
Agatha Sevilla Maharia ${ }^{1}$, Muhamad Muhdar ${ }^{2}$, Rahmawati Al Hidayah ${ }^{3}$ \\ gathasevilla.asm@gmail.com,muhamadmuhdar@fh.unmul.ac.id, \\ rahmawatialhidayah@fh.unmul.ac.id \\ ${ }^{123}$ Universitas Mulawarman Samarinda, Kalimantan Timur
}

\begin{abstract}
ABSTRAK
Indonesia ikut serta dalam skema jual-beli karbon sebagai upaya mitigasi perubahan iklim. Karbon merupakan benda tidak berwujud yang diperjualbelikan berdasarkan pada perjanjian. Penelitian ini diajukan untuk menjawab dua pertanyaan, pertama menganalisis skema perdagangan karbon menurut Hukum Perdata khususnya jual-beli. Kedua menganalisis mengenai Certified Emissions Reductions (CER) sebagai bukti objek transaksi Carbon Crediting. Dalam sistem hukum perdata Indonesia tidak mengenal karbon sebagai objek hukum, meskipun Indonesia telah melakukan jual-beli karbon sehingga praktek ini dapat direplikasi sebagai objek hukum tidak berwujud. Hak kepemilikan dari karbon ditandai dengan CER yang berpotensi sebagai peneguhan objek kepemilikan karbon belum dapat dipastikan. Pada akhirnya dapat berakibat pada adanya konflik dimasyarakat karena hak karbon dan pembagian manfaat dari jual beli karbon belum dapat dipastikan.
\end{abstract}

Kata Kunci: Certified Emissions Reductions, Karbon, Jual-beli, objek hukum

\section{ABSTRACT}

Indonesia involves in carbon trading scheme as an effort of climate change mitigation. Carbon is intangible asset that is traded based on an agreement. This research aimed to answer two research questions. First, to analyze carbon trading scheme based on civil law, especially buying and selling activities. Second, to analyze Certified Emission Reduction (CER) as a proof in transactional of Carbon Crediting. Indonesian civil law system did not recognized carbon as law object even though Indonesia had done carbon trading. Thus this practic could be replicated as intangible object of law. The Ownership right of carbon was recognized by CER which was potential affirmation of ownership carbon object. At the end, it could affect conflict in society because carbon right and benefit sharing from carbon trading could not be predicted.

Keywords: Certified Emissions Reduction; Carbon; Selling-Buying activities; Legal Object 


\section{PENDAHULUAN}

\section{A. Latar Belakang}

Energi matahari memiliki fungsi utama yaitu untuk menyeimbangkan suhu di bumi. ${ }^{1}$ Bumi sendiri telah memiliki berbagai macam gas diatmosfer yang melindungi bumi dari panas matahari yang berlebih. ${ }^{2}$ Atmosfer adalah udara yang tersusun dari gas tidak terlihat seperti nitrogen, oksigen, karbon dioksida, dan gas-gas lainnya. ${ }^{3}$ Atmosfer sendiri terbentuk dari permukaan bumi hingga angkasa luar dengan banyak lapisan. Fungsi dari gas-gas di atmosfer ini yaitu untuk mengatur jumlah energi matahari yang sampai ke bumi yang membuat bumi semakin hangat atau semakin dingin. ${ }^{4}$ Lapisan atmosfer yang menebal mengakibatkan energi matahari yang harusnya dapat kembali dipantulkan kembali ke atmosfer, menjadi tidak dapat dipantulkan yang mengakibatkan bumi menjadi lebih panas, selain itu menggangu iklim di bumi sehingga cuaca dibumi menjadi tidak menentu. ${ }^{5}$

Jumlah gas rumah kaca di atmosfer semakin meningkat sejak 150 tahun terakhir. $^{6}$ Meningkatnya konsentrasi gas rumah kaca disebabkan karena kegiatan manusia seperti kegiatan industri yang memerlukan banyak sumber energi seperti minyak, batubara dan gas bumi. Pembakaran bahan bakar ini akan melepaskan karbondioksida (CO2) ke udara. ${ }^{7}$ Dengan meningkatnya konsentrasi gas rumah kaca di atmosfer, maka yang akan terjadi adalah pemanasan global (global warming). ${ }^{8}$ Pemanasan global menyebabkan peningkatan resiko bencana. ${ }^{9}$ Pemanasan global yang saat ini terjadi dapat membahayakan keberlangsungan kehidupan manusia dan makhluk hidup lainnya karena suhu dibumi akan semakin naik yang menyebabkan bumi tidak lagi sesuai untuk kehidupan manusia. ${ }^{10}$ Untuk menangani perubahan iklim maka diperlukan dua pendekatan yaitu mitigasi dan adaptasi. Mitigasi diperlukan untuk memperlambat laju perubahan iklim, dan adaptasi yaitu untuk menyesuaikan diri terhadap resiko dari perubahan iklim yang telah terjadi maupun yang akan terjadi. $^{11}$

Efek perubahan iklim yang terjadi telah dijelaskan di dalam UNFCCC yang terdapat pada Article 1 (1) United Nations Framework Convention on Climate Change:

\footnotetext{
${ }^{1}$ Susan Stone., at, all, 2010, Perubahan Iklim dan Peran Hutan: Manual KomunitasI, Conservation International hlm 6

${ }^{2}$ Ibid

${ }^{3}$ Ibid hlm 5

${ }^{4}$ Ibid hlm 6

5,2013, Mari Berdagang Kerbon! Pengantar Pasar Karbon Untuk Pengendalian Perubahan Iklim, Dewan Nasional Perubahan Iklim, Jakarta, hlm 9

${ }^{6}$ Ibid hlm 6

${ }^{7}$ DNPI, Loc.cit

${ }^{8}$ Ibid

${ }^{9}$ PMR, Pasar Karbon, PMR Indonesia, Jakarta, hlm 9

${ }^{10}$ Abdul Razak, Kajian Yuridis Carbon Trade dalam Penyelesaian Efek Rumah Kaca, Makalah Etika dan Kebijakan Perudangan Lingkungan, UGM Yogyakarta, hlm 9

${ }^{11}$ Susan Stone, Op.cit., hlm 23
} 
"Changes in the physical environment or biota resulting from climate change which have significant deleterious effects on the composition. Resilience or procuctivity of natural and managed ecosystems or on the operation of sicoi economic system or on human health and welfare." 12

Untuk memperbaiki efek dari kerusakan iklim yang terjadi, Negara-negara di dalam konvensi kerangka kerja PBB (Perserikatan Bangsa-Bangsa) membuat sebuah perjanjian lingkungan internasional yang disebut dengan UNFCCC (United Nation Framework Convention on Climate Change) yang dirundingkan pada KTT Bumi di Rio de Janerio pada 3-14 Juni 1992 dan mulai diberlakukan pada 21 Maret 1994. UNFCCC memiliki prinsip tanggung jawab bersama tetapi berbeda (common but differentiated principle). ${ }^{13}$ Maksud dari prinsip ini mengacu pada kenyataan bahwa Negara AnnexI yang melepaskan gas rumah kacanya terlebih dahulu di atmosfer saat membangun negaranya masing-masing, maka dari itu Negara AnnexI memiliki tanggung jawab lebih besar untuk menurunkan emisi gas rumah kaca. ${ }^{14}$ Tujuan utama dari konvensi ini adalah menstabilkan konsentrasi gas rumah kaca seperti karbon dioksida (CO2), metana (CH4), dinitroksida (N2O), sulfur heksaflourida (SF6), hidroflouorokarbon (HFC), dan perfluorokarbon (PFC) yang merupakan akibat dari kegiatan manusia. Dalam konvensi ini memberikan tanggung jawab kepada negara AnnexI atas tingginya emisi karbon yang terjadi. Negara AnnexI adalah negara-negara yang telah melepaskan gas rumah kaca ke atmosfer sejak awal revolusi industri tahun $1850 .{ }^{15}$ Dalam konvensi UNFCCC menjadi dasar lahirnya Kyoto Protocol to the United Nations Framework Convention on Climate Change atau Protokol Kyoto. Protokol Kyoto mulai berlaku setelah $55 \%$ anggota di dalam konvensi perubahan iklim tersebut meratifikasi.

Setelah terciptanya Protokol Kyoto yang merupakan hasil dari konvensi UNFCCC, negara-negara yang tergabung di dalam konvensi PBB setuju untuk menciptakan suatu kebijakan sebagai bentuk adaptasi dan mitigasi perubahan iklim di dunia. Di dalam Protokol Kyoto terdapat mekanisme yang disebut sebagai Flexible Mechanism. ${ }^{16}$ Flexible Mechanism atau mekanisme fleksibel terdiri dari tiga mekanisme perdagangan karbon yang dapat dilakukan oleh negara AnnexI ataupun negara Non-AnnexI yaitu, Emission Trading (ET), Joint Implementation (JI), dan Clean Development Mechanism (CDM). Emission trading terdapat pada Pasal 17 Protokol Kyoto yang memungkinkan negara AnnexI menjual kredit penurunan emisi karbonnya kepada negara AnnexI lainnya.

Joint Implementation merupakan salah satu mekanisme yang terdapat pada Protokol Kyoto. Joint Implementation bertujuan untuk membantu negara AnnexI lainnya untuk menurunkan emisi karbonnya dengan melakukan perdagangan karbon berbasis proyek. Negara non-AnnexI juga dapat melakukan perjanjian perdagangan karbon melalui Clean Development Mechannism (CDM). Clean Development Mechanism atau CDM merupakan

\footnotetext{
12 UNFCCC article 1.1

13 Takdir Rahmadi, 2013, Hukum Lingkungan di Indonesia, Rajawali Pers, Jakarta, hlm 19

${ }^{14}$ DNPI, Op.cit. hlm 11

${ }^{15}$ Wahana Lingkungan Hidup Indonesia (WALHI) Bali, https://walhibali.org/lembar-informasi-2/ diakses terakhir pada 1 April 2019

${ }^{16}$ DNPI Op.cit hlm 27
} 
satu-satunya mekanisme penurunan emisi karbon yang melibatkan negara Non-AnnexI. CDM adalah sebuah mekanisme kerjasama antara negara AnnexI dengan negara Non-AnnexI dengan cara negara AnnexI menanamkan modal untuk membuat proyek-proyek rendah karbon di negara Non-AnnexI yang setiap karbon yang dapat dikurangi yang dimuat di dalam sebuah Certified Emission Reductions atau CER. Setiap upaya penurunan emisi yang setara dengan satu ton karbon akan dinilai dengan satu CER. CDM juga bertujuan untuk membantu negara berkembang atau Non-AnnexI dalam pembangunan yang berkelanjutan. ${ }^{17}$ Setelah meratifikasi Protokol Kyoto dalam Undang-Undang Nomor 17 Tahun 2004, Indonesia mulai aktif dalam kegiatan perdagangan karbon. Bukan hanya satu jenis model pasar karbon dan perdagangan karbon yang diimplementasikan tetapi upaya dan model pembiayaan lain berbasis mekanisme pasar. ${ }^{18}$

Dalam Pasal 1457 KUH Perdata jual-beli adalah persetujuan dengan mana pihak yang satu mengikatkan dirinya untuk menyerahkan suatu barang dan pihak yang lain untuk membayar harga yang dijanjikan. Pada Pasal 499 KUH Perdata, definisi dari barang adalah segala sesuatu yang dapat diberi hak atau dapat dijadikan objek hak milik. ${ }^{19}$

Hukum Perdata Indonesia tidak mengatur mengenai karbon sebagai objek hukum jualbeli. Dalam hukum kebendaan Indonesia yang berdasarkan Kitab Undang-Undang Hukum Perdata (KUH Perdata) tidak mengenal adanya hak kebendaan pada karbon (carbon property rights). Namun, dalam analogi hukum dan prakteknya mengakui objek-objek hukum tidak berwujud dalam transaksi seperti pulsa telekomunikasi maupun pulsa listrik, penanda transaksi hanya tervalidasi melalui bukti pembelian. CER sebagai bukti validasi jual-beli karbon berpotensi dianalogikan sama seperti bukti transaksi benda tidak berwujud lainnya, walaupun karbon belum ditentukan sebagai suatu objek. Kekosongan pengaturan atas carbon property rights dalam sistem Hukum Perdata Indonesia menunjukkan bahwa Indonesia menghadapi masalah pada tingkat kesiapan pengaturan mengenai skema perdagangan karbon.

\section{B. Rumusan Masalah}

Tulisan ini diajukan untuk menguji dua hal, pertama, bagaimana skema perdagangan karbon menurut hukum perdata khususnya dalam hubungan hukum jual-beli, Kedua, bagaimana Certified Emissions Reductions (CER) sebagai bukti objek transaksi Carbon Crediting.

\section{Metode}

Dalam penelitian ini menggunakan pendekatan doktrinal. Pendekatan doktrinal mengandung karakter normatif oleh karena memiliki sasaran penelitian berupa sekumpulan norma. Penelitian dilakukan secara kualitatif dengan bertumpu pada studi

\footnotetext{
${ }^{17}$ Bernadius Stein dalam Laurens Bekker dan Fristikawati (ed), 2014, Permasalahan Kehutanan di Indonesia dan Kaitannya Dengan Perubahan Iklim Serta REDD+, Pohon Cahaya: Yogyakarta, hlm 15

${ }^{18}$ Dicky Edwin Hindarto, at.all, 2018, Pasar Karbon: Pengantar Pasar Karbon untuk Perubahan Iklim, PMR Indonesia, Jakarta, hlm 3

${ }^{19}$ KUHPerdata Pasal 499 Barang adalah tiap benda dan tiap hak yang dapat menjadi objek hak milik
} 
kepustakaan (library research), terutama melakukan sistematisasi berbagai prinsip pengelolaan carbon dalam hubungannya dengan perubahan iklim dalam berbagai skema pengaturan pada level internasional dan nasional.

\section{Tinjauan Pustaka}

Objek hukum ialah segala sesuatu yang dapat menjadi hak dari subjek hukum atau segala sesuatu yang dapat menjadi objek dari suatu perhubungan hukum. ${ }^{20}$ Dalam KUH Perdata, kebendaan ialah tiap-tiap barang dan tiap-tiap hak, yang dapat dikuasi oleh hak milik. Arti kata "dapat" memiliki arti yang penting yaitu pada saat tertentu sesuatu itu belum berstatus sebagai objek hukum, namun pada saat lain merupakan objek hukum seperti aliran listrik. ${ }^{21}$ Untuk menjadi suatu objek hukum maka harus memenuhi syaratsyarat tertentu, yaitu penguasaan manusia, mempunyai nilai ekonomi, dapat dijadikan sebagai objek perbuatan hukum. ${ }^{22}$ Objek hukum dapat juga diartikan sebagai segala sesuatu yang dapat dinilai dengan uang, memiliki nilai affektif, berdiri sendiri dan merupakan satu kesatuan maka dapat dikatakan benda jika dapat dikuasai oleh manusia, dapat diraba atau tidak, dapat dinilai dengan uang atau berharga untuknya dan merupakan satu kesatuan yang berdiri sendiri. ${ }^{23}$ Udara di ruang angkasa tidak dapat dianggap sebagai suatu benda karena benda harus menghasilkan kemandirian, tetapi udara yang telah dimasukkan kedalam sebuah tabung dapat diartikan sebagai benda. ${ }^{24}$

Dalam prespektif hukum perdata, hukum benda merupakan hukum kekayaan mutlak atau suatu ketentuan yang mengatur tentang hak kebendaan dan barang-barang tak berwujud. ${ }^{25}$ Hukum mempunyai tugas suci dan luhur yaitu keadilan yang diberikan kepada tiap orang yang berhak ia terima dan memerlukan peraturan tersendiri pada kasus tertentu. Hukum harus membuat sebuah ketentuan umum atau peraturan yang diperlukan masyarakat demi kepastian hukum. Kepastian hukum merupakan sebuah jaminan harus dijalankan dengan baik. ${ }^{26}$ Kepastian hukum menghendaki adanya upaya pengaturan hukum dalam perundang-undangan yang dibuat oleh pihak yang berwenang, sehingga aturan itu memiliki aspek yuridis yang dapat menjamin bahwa hukum berfungsi sebagai suatu peraturan yang harus ditaati dan tujuan hukum yaitu menjamin terwujudnya kepastian hukum. ${ }^{27}$

Kepastian hukum dalam upaya adaptasi dan mitigasi perubahan iklim yaitu membuat suatu kebijakan Internasional yaitu Protokol Kyoto yang mulai dibahas saat COP ketiga di Kyoto, Jepang. Pada COP pertama dan kedua membahas tentang perubahan iklim yang sedang terjadi yang dikuatkan dengan temuan dari IPCC yang menjadi dasar dibuatnya sebuah protokol perubahan iklim. Setelah disepakatinya Protokol Kyoto, menjadi awal mula kebijakan Internasional lainnya dibuat seperti Buenos Aires Plan of Action, Bonn Agreement,

\footnotetext{
${ }^{20}$ Mariam Darus Badrulzaman, 1983. Mencari Sistem Hukum Benda Nasional. Alumni Bandung hlm 35 dalam Frieda Husni Hasabullah, 2002. Hukum Kebendaan Perdata, Hil-Co, Jakarta Selatan hlm 21

${ }^{21}$ Ibid

22 Ibid

${ }^{23}$ Ibid hlm 28

${ }^{24}$ Vollmar, Op.cit, hlm 192 dalam Ibid hlm 29

25 Titik Triwulan Tutik, 2008. Hukum Perdata Dalam Sistem Hukum Nasional Kencana. Jakarta hlm 141142 dalam Rachmadi Usman, 2013. Hukum Kebendaan. Sinar Grafika, Jakarta hlm 1

${ }^{26}$ Sudikno Mertokusumo, 2012. Teori Hukum. Gudang Penerbit. Jakarta hlm 45

${ }^{27}$ Ibid
} 
Amandemen Doha, hingga Paris Agreement sebagai kebijakan yang akan diterapkan setelah komitmen Protokol Kyoto periode kedua selesai. Protokol Kyoto merupakan refleksi dari keinginan masyarakat dunia untuk mengurangi gas rumah kaca yang terjadi di atmosfer, yang setiap hari semakin meningkat. Peningkatan gas-gas ini telah hampir merata diseluruh dunia. $^{28}$ Dengan adanya target penururnan emisi, maka sasaran Protokol Kyoto adalah mengikat secara hukum (legally binding), adanya periode komitmen (commitment period), digunakannya rosot (sink) untuk mencapai target, adanya jatah emisi (assigned amount) setiap pihak Annex-1, dimasukannya enam jenis Gas Rumah Kaca (GRK) (basket of gases). ${ }^{29}$ Protokol Kyoto implikasinya dapat dikelompokkan dalam tiga aspek, yaitu aspek politik dan hukum, aspek bisnis, dan aspek kelembagaan. ${ }^{30}$ Aspek bisnis perdagangan karbon melibatkan pihak penjual dan pembeli. Pembayaran berupa harga atas jasa lingkungan dalam upaya peningkatan cadangan karbon dan upaya mengurangi deforestasi dan degradasi hutan. ${ }^{31}$

Dengan meratifikasi Protokol Kyoto tersebut maka Indonesia akan memiliki komitmen terhadap negara-negara lain yang lebih dahulu meratifikasi perjanjian tersebut. Ratifikasi Protokol Kyoto merupakan sebuah kesepakatan internasional yang menunjukkan upaya yang sangat serius dalam menghadapi peruhahan iklim. Secara hukum Protokol Kyoto mewajibkan seluruh negara AnnexI untuk secara bersama-sama menurunkan emisi gas rumah kaca. ${ }^{32}$ Clean Development Mechanism (CDM) di sektor kehutanan lahir karena pandangan terhadap fungsi dan peran hutan tropis yang dianggap sebagai paru-paru dunia. Negara yang memiliki hutan tropis harus mendapatkan kompensasi atas penyediaan paru-paru dunia tersebut. CDM merupakan bentuk kompensasi dari negara maju kepada negara berkembang, CDM merupakan peluang memperoleh dana luar negeri untuk menciptakan lapangan kerja dengan adanya investasi baru. Manfaat tidak langsung yang dapat dipetik Indonesia dapat berupa technology transfer, capacity building, peningkatan kualitas ingkungan, serta peningkatan daya saing. ${ }^{33}$

CER sebagai bukti transaksi perdagangan karbon merupakan yang dapat digunakan oleh para pihak, ${ }^{34}$ dan menjadi instrument penyelenggaraan ekonomi yang efisien dalam mengurangi dampak buangan emisi. ${ }^{35}$

\section{PEMBAHASAN}

\footnotetext{
${ }^{28}$ Supardi, 2008. Hukum Lingkungan di Indonesia. Sinar Grafika, Jakarta hlm 63

${ }^{29}$ Ibid hlm 72

${ }^{30}$ Daniel Murdiyarso, 2003, Protokol Kyoto, Implikasi Bagi Negara Berkembang, Buku Komas, Jakarta hlm 1-2 dalam Ibid

31 Sanusi, Mujibussalim, Fikri, Perdagangan Karbon Hutan Aceh: Analisis Hukum Pada Tahapan Perencanaan, No.59 Th.XV (April, 2013), hlm 44

${ }^{32}$ DNPI, Op.cit, hlm 47

${ }_{33}$ Danang Kuncara Sakti , 2005, Program Pascasarjana Universitas Indonesia, Dampak Protokol Kyoto Melalui Clean Development Mechanism PAda Sektor Kehutanan Terhadap Perekonomian Indonesia Sistem Neraca Sosial Ekonomi, hlm 3

${ }^{34}$ Lihat juga, United Nations Climate Change, Emissions Trading, Greenhouse gas emissions a new commodity, available at: https://unfecc.int/process/the-kyoto-protocol/mechanisms/emissions-trading, last accesed July 8, 2020

35 Lihat OECD, Emission Trading System, available at: https://www.oecd.org/environment/toolsevaluation/emissiontradingsystems.htm, last accesed July 8, 2020
} 


\section{Skema Perdagangan Karbon Menurut Hukum Perdata Khususnya Hukum Jual-Beli}

Kesepakatan Paris (COP-21) tahun 2015 merupakan merupakan kesepakatan fundamental dalam skema perubahan iklim karena memiliki kekuatan mengikat (legally binding) sejak isu-isu ini diputuskan pada Protokol Kyoto (COP-3). ${ }^{36}$ Respon dunia merespon terhadap efek gas rumah kaca kian terasa. GHG berkontribusi meningkatkan suhu atmosfer sehingga $2^{\circ} \mathrm{C}$ yang memiliki dampak pada fenomena seperti es yang mencair, naiknya permukaan air laut, kekeringan, banjir, dan badai. Dampak yang lebih berkelanjutan dapat berupa hilangnya nyawa, wilayah, keanekaragaman hayati, dan masalah Kesehatan, ${ }^{37}$ atau sejalan dengan sasaran Protokol Kyoto, yaitu:

1. Mengikat secara hukum (legally binding),

2. Adanya periode komitmen (commitment period),

3. Digunakannya rosot (sink) untuk mencapai target,

4. Adanya jatah emisi (assigned amount) setiap pihak Annex-1,

5. Dimasukannya enam jenis Gas Rumah Kaca (GRK) (basket of gases). ${ }^{38}$

Protokol Kyoto implikasinya dapat dikelompokkan dalam tiga aspek, yaitu aspek politik dan hukum, aspek bisnis, dan aspek kelembagaan. ${ }^{39}$ Aspek bisnis perdagangan karbon melibatkan pihak penjual dan pembeli. Pembayaran berupa harga atas jasa lingkungan dalam upaya peningkatan cadangan karbon dan upaya mengurangi deforestasi dan degradasi hutan. $^{40}$

Konvensi perjanjian internasional di bawah Perserikatan Bangsa-Bangsa (PBB) tentang United Nations Framework Convention on Climte Change (UNFCCC). Konvensi ini telah diratifikasi oleh 193 negara, dan ikut mempengaruhi persepsi banyak negara dalam Kesepakatan Paris (2015). ${ }^{41}$ Indonesia meratifikasi UNFCCC dalam Undang-Undang Nomor 6 tahun 1994. Dalam konvensi UNFCCC dirumuskan sebuah protokol Kyoto pada tahun 1997. Dalam UNFCCC terdapat prinsip common but differentiated responsibility yaitu tanggung jawab yang berlaku umum tetapi berbeda. Prinsip ini yang mendasari pengembangan pasar karbon.

Dalam proses negosiasi jual-beli karbon, masyarakat juga aktif idalam proses negosiasi tetapi di dalam prakteknya hanya negra-negara peserta UNFCCC saja yang dalam melakukan pengambilan keputusan pada saat COP berlangsung. Dalam UNFCCC sebanyak $70 \%$ delegasi negara memiliki anggota masyarakat dan sebanyak $18 \%$ delegasi nasional merupakan anggota dari NGO. ${ }^{42}$ Keterlibatan masyarakat, kelompok-kelompok yang terdapat

\footnotetext{
${ }^{36}$ United Nations Climate Change, What is the Paris Agreement? Available at: https://unfccc.int/process-andmeetings/the-paris-agreement/what-is-the-paris-agreement, last accesed July 8, 2020

${ }^{37}$ Ottavio Quirico et, al, 2016. Climate Changes and Human Rights an International and comparative law perspective. Routledge: New York. hlm 3

${ }^{38}$ Supardi, 2008, Hukum Lingkungan di Indonesia, Sinar Grafika, Jakarta, Ibidi hlm 72

${ }^{39}$ ibid

${ }^{40}$ Sanusi, Mujibussalim, Fikri, Perdagangan Karbon Hutam Aceh: Analisis Hukum Pada Tahapan Perencanaan, No. 59, Th. XV (April, 2013), pp. 41-63, hlm. 44.

${ }^{41}$ Ibid, hlm 11

${ }^{42}$ Mizan R. Khan, 2014, Toward a Binding Climate Cange Adaptation Regime: A Proposed Framework, Florence Production Ltd: United Kingdom, page 147
} 
dalam mengatasi dampak perubahan iklim pada kehidupan dan mata pencarian meereka. Pada article 25.1 of the Universal Declaration of Human Right (UDHR):

"Everyone has the right to a standard of living adequate for the health and well-being of himself and of his family, including food, clothing, housing and medical care necessary social services, and the right to security in the event of unemployment, sickness, disability, widowhood, old age or other lack of livelihood in circumstances beyond his control." 43

Istilah karbon masih belum dipahami secara mendalam di masyarakat. Karbon yang menjadi komoditas dianggap seperti arang (charcoal), bukan karbondioksida (CO2). ${ }^{44}$ Karbondioksida bukan satu-satunya jenis karbon yang diperjualbelikan. Dalam pasar karbon yang diperdagangkan adalah CER sebagai bentuk bukti validasi atas karbon yang dijual. CER merupakan bukti hak atas emisi gas rumah kaca yang dihitung satu ton karbon setara dengan satu sertifikat. Hak atas emisi merupakan hak untuk melepaskan gas rumah kaca, atau hak untuk menurunkan gas rumah kaca. ${ }^{45}$ Selain karbondioksida, di dalam pasar karbon umunya ada enam jenis gas yang diperdagangkan. Gas rumah kaca yang diperdagangkan yaitu Karbon dioksida (CO2); Metana (CH4); Nitrat oksida (N2O); Hidrofluorokarbon (HFCs); Perfluorocarbons (PFCs); dan Sulfur heksafluorida (SF6). ${ }^{46}$

Dalam Global Warning Potential (GWP) karbon dioksida memiliki angka 1, dan lima gas rumah kaca lainnya seperti metana (CH4) memiliki angka GWP sebesar 21, artinya 1 Ton metana memiliki potensi 21 kali lebih besar dibandingkan dengan 1 Ton karbon dioksida. Pada bagian lain, pengurangan 1 ton gas metana setara dengan mengurangi karbon dioksida sebanyak 21 ton karbon equivalent. ${ }^{47}$ Sebagai contoh, Provinsi Kalimantan Timur pada periode 2005-2015 terjadi deforestasi sebesar $57.954 \mathrm{Ha} /$ tahun. ${ }^{48}$ Deforestasi yang terjadi di Kalimantan Timur menyumbangkan emisi gas rumah kaca yang besar ke udara sebesar $56 \%$ atau 20.355.102,20 ton CO2/tahun, emisi dari hutan bakau sebesar 21\% atau 7.644.707,64 tons $\mathrm{CO} 2 /$ tahun, akitivas pembukaan lahan sebesar 17\% atau 6.053.610,20 tons $\mathrm{CO} 2 /$ tahun, degradasi hutan sebesar 4\% atau 1.480.355,99 tons $\mathrm{CO} 2 /$ tahun, dan yang berasal dari lahan gambut sebesar $2 \%$ atau $608.057,33$ tons $\mathrm{CO} 2 /$ tahun. Total $\mathrm{CO} 2$ yang dihasilkan pertahun adalah sekitar 36.143.844 tons $\mathrm{CO} 2 .{ }^{49}$

Table 1. Jenis Gas Rumah Kaca dalam Global Warning Potential

\begin{tabular}{lc}
\hline \multicolumn{1}{c}{ Jenis Gas } & Global Warning Potential \\
\hline Karbon Dioksida (CO2) & 1 \\
Metana (CH4) & 21 \\
Nitrat Oksida (N2O) & 310 \\
Perfluorocarbons (PFCs) & $6.500-9.200$ \\
Hidrofluorokarbon (HFCs) & $140-11.700$ \\
Sulfur heksafluorida (SF6) & 23.900 \\
\hline
\end{tabular}

\footnotetext{
${ }^{43}$ Ibid hlm 149

${ }^{44}$ PMR, Op.cit. hlm 29

${ }^{45}$ DNPI, Op.cit hlm 16

${ }^{46}$ Ibid. hlm 15

${ }^{47}$ Ibid

${ }^{48}$ Muhamad Muhdar, Haris Retno S. dan Sopialena, High Conservation Value (Hcv) Consideration In The Extrication Of Forest Area For Palm Plantation, TALREV vol 4 Issues 2 Hlm 116

${ }^{49}$ Ibid
} 
Untuk memperdagangkan karbon, terdapat dua jenis pasar karbon yang berbeda yaitu Trading yang merupakan pasar karbon antara Negara Annex 1-Annex 1 dan Crediting sebagai pasar karbon yang di dalamnya Negara Non-Annex 1-Annex 1 melakukan perjanjian perdagangan karbon. Pada pasar karbon Trading biasa disebut dengan cap and tradeyang merupakan sistem yang menerapkan adanya pembatasan emisi gas rumah kaca pada para pihak dalam pasar karbon.

Gambar 1. Sistem Trading atau Cap and Trade

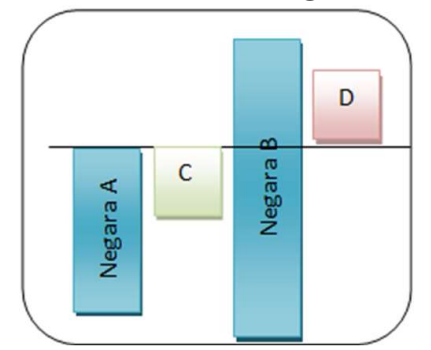

Sumber: Diolah dan diilustrasikan oleh penulis

Pada sistem Crediting atau yang disebut dengan Baseline and Crediting adalah pasar karbon. Dalam sistem ini komoditi yang diperjualbelikan adalah karbon yang dibuktikan dengan sertifikasi penurunan emisi yang telah diverifikasi dan disertifikasi yaitu Certified Emissions Reduction (CER) atau dapat disebut dengan kredit karbon oleh Designated Operational Entity yang dapat berupa badan hukum yang telah terakreditasi dan ditunjuk oleh executive board. Tujuan pembelian kredit karbon ini adalah untuk menggantikan (offsetting) emisi gas rumah kaca yang dilepaskan diudara karena akibat adanya sebuah kegiatan. Dengan membeli kredit karbon, pembeli karbon dapat menggantikan emisi gas rumah kacanya.

Gambar 2. Sistem Crediting atau Baseline and Crediting

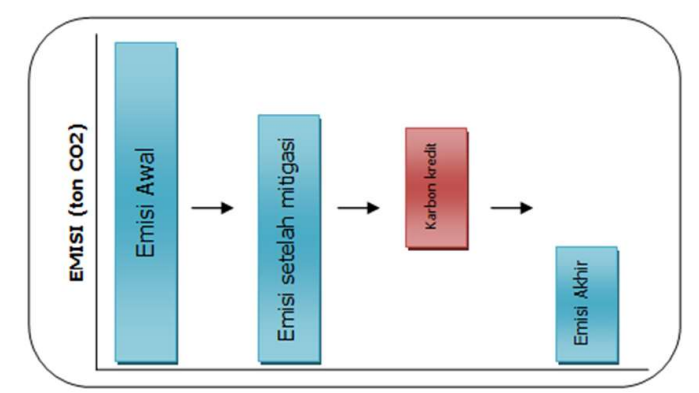

Sumber: Diolah dan diilustrasikan oleh penulis

Hubungan hukum antara pemilik dan penjual karbon diatur dalam perjanjian yang disebut dengan Emission Reduction Purchase Agreement atau (ERPA). Emission Reduction Purchase Agreement dapat dibagi dalam 2 jenis, yaitu:

${ }^{50} \mathrm{DNPI}$, op.cit hlm 16 
ISSN (Print): 2085-8477; ISSN (Online): 2655-4348

1. Emission Reduction Purchase Agreement yang berisi kesepakatan melakukan jualbeli kredit karbon dari proyek-proyek yang telah dilakukan dan yang diperjanjikan.

2. Emission Reduction Purchase Agreement yang berisi kesepakatan bahwa pembeli karbon juga ikut dalam proyek yang dilaksanakan seperti pemilihan lokasi proyek, penentuan harga dan lain-lain. ${ }^{51}$

Dalam jual-beli karbon, karbon yang awalnya bukan merupakan suatu objek menjadi suatu objek karena karbon juga memiliki nilai serta menjadi objek dari suatu perjanjian. Karbon merupakan benda tidak berwujud yang menyebabkan dibuatnya suatu perjanjian jualbeli karbon untuk mencatatkan perjanjian karbon antar para pihak, mengidentifikasi tanggung jawab antar para pihak, menetapkan pengelolaan resiko terhadap proyek. Dalam jual-beli karbon dilakukan dengan pencatatan di dalam sebuah sertifikat sebagai bentuk validasi atas karbon yang diperjual-belikan yang disebut CER, dengan adanya suatu perjanjian tersebut maka sertifikat tersebut akan berpindah setelah adanya verifikasi. Tetapi karbon belum ditentukan karbon menjadi satu kesatuan dengan pohon, karbon merupakan sumber daya yang tidak dapat dihaki atau karbon merupakan suatu benda yang berdiri sendiri.

\section{Status CER Sebagai Bukti Obyek Transaksi Carbon Crediting}

Perjanjian bersifat obligatoir yang artinya dengan selesainya perjanjian, tujuan pokok tersebut belum selesai karena menimbulkan hak dan kewajiban antara para pihak, apabila hak belum beralih karena penyerahan benda belum dilakukan. Perjanjian jual-beli baru melekat hak dan kewajiban oleh para pihak yang menjadi timbal balik antara penjual dan pembeli saat terjadi kesepakatan. Dengan adanya kesepakatan tersebut maka penjual berkewajiban menyerahkan suatu barang dan menuntut hak pembayaran atas barang tersebut kepada pembeli. Pemindahan hak milik baru berpindah saat setelah dilakukannya penyerahan (levering). Hak milik sebagai hak orisinal karena manusia mempunyai akal pikiran untuk menguasai benda atau objek. ${ }^{52}$ Tanpa hak milik manusia hanya sebagai the living being bukan merupakan the existential being. ${ }^{53}$ Dalam perjanjian jual-beli karbon, dilakukan sebuah perjanjian yang disebut dengan Emission Reduction Purchase Agreement (ERPA).

Perjanjian jual-beli karbon terjadi walaupun karbon belum dikenal sebagai suatu benda di dalam hukum kebendaan karena sifat hukum kebendaan yang tertutup. Tetapi, dengan adanya perikatan yaitu suatu perjanjian ERPA maka karbon dapat dikatakan sebagai suatu objek hukum yang sah seperti halnya dengan pulsa elektronik ataupun pulsa listrik yang merupakan benda tidak berwujud tetapi memiliki nilai seperti karbon. Karbon dapat dikuasai oleh manusia walaupun karbon merupakan benda tidak berwujud. Untuk menjadi suatu objek hukum maka harus memenuhi syarat-syarat tertentu, yaitu penguasaan manusia, memiliki nilai manfaat bagi subyek hukum, dan memiliki kejelasan dari sisi objek sebagai basis hubungan hukum.

\footnotetext{
${ }^{51}$ Erna Mieke Naibaho, 2011, Program Pascasarjana Univesitas Indonesia, Tinjauan Hukum Dalam Perdagangan Kredit karbon, hlm 41

52 Peter Mahmud Marzuki, 2008, Pengantar Ilmu Hukum Edisi Revisi, Kencana Prenadamedia Group, Jakarta, hlm 161

53 Ibid hlm 162
} 
Penguasaan terhadap karbon karena karbon merupakan satu kesatuan dengan sumber daya alam hayati dan sumber daya alam non-hayati. Penguasaan yang dimaksud disini adalah penggunaan sumber daya. Sumber daya alam non-hayati berupa matahari, udara, gas bumi, batubara, dan hasil tambang lainnya. Penguasaan dan pengunaan sumber daya ini dapat ditekan agar tidak menghasilkan karbon yang berlebih. Karbon juga terdapat pada sumber daya alam hayati seperti pepohonan dan tumbuhan. Penguasaan terhadap sumber daya hayati ini juga memiliki peran penting dalam mengatasi karbon di udara. Perpindahan kepemilikan kredit karbon dalam kaitannya dengan jual-beli karbon dimulai dengan ditandatanganinya ERPA, maka penjual sepakat menyerahkan sejumlah karbon kredit yang dibuktikan dengan CER seperti yang telah diperjanjikan kepada pembeli. Karbon yang bernilai ekonomis adalah karbon yang telah diverifikasi oleh pihak yang berwenang dan telah dicatatkan di dalam sebuah sertifikat sesuai dengan peraturan dalam jual-beli karbon.

CER merupakan satuan kredit karbon yang menjadi objek perjanjian ERPA. Penyerahannya dilakukan dengan pemindahbukuan yang menjadi transaksi pada pasar karbon. CER menjadi sebuah objek perjanjian yang artinya CER merupakan kebendaan, karena telah menjadi objek jual beli yang merupakan suatu perbuatan hukum. Hukum kebendaan Indonesia yang sifatnya tertutup, tidak mengenal karbon sebagai suatu kebendaan pada umumnya. Apabila dilihat pada Pasal 1457 KUHPerdata tentang perjanjian jual beli, karbon kredit merupakan sebuah benda karena telah menjadi objek dari suatu perjanjian. Sesuatu dapat dikatakan sebagai benda apabila sekurang-kurangnya memiliki nilai affektif atau dapat dinilai dengan uang. Karbon yang awlanya belum dikenal sebagai suatu benda dan memiliki nilai, menjadi suatu benda yang memiliki nilai karena karbon mengalami komodifikasi. Komodifikasi yaitu sesuatu yang awalnya tidak memiliki nilai menjadi sesutau yang memiliki nilai jual dan dapat diperjual belikan. ${ }^{54}$ Kredit karbon memiliki kemiripan karakteristik dengan komoditas pada umumnya, maka kredit karbon dapat dikatakan sebagai sebuah komoditas yang dapat diperjualbelikan dalam mekanisme pasar. Karbon dijadikan sebagai sebuah objek yang kepemilikannya dapat berpindah dengan dengan cara diperjualbelikan melalui perjanjian yang disebut ERPA. Karbon dilihat sebagai objek pokok perjanjian karena karbon memiliki karakteristik yang sama dengan komoidtas pada umumnya dan dijadikan sebagai sebuah objek hubungan hukum.

\section{PENUTUP}

Perjanjian jual-beli dalam perspektif KUH Perdata menganut sistem keterbukaan. Pada perjanjian jual-beli karbon dalam skema CDM menetapkan kualifikasi tertentu dalam ERPA. ERPA merupakan bentuk perjanjian jual beli kredit karbon yang telah sesuai dengan syaratsyarat sah dari suatu perjanjian yang telah diatur dalam KUHPerdata. Dalam kebijakan hukum yang dibuat untuk karbon kredit di Indonesia, karbon dikategorikan sebagai benda dan hak-hak atas karbon yaitu hak-hak atas karbon hutan sehingga penguasaan karbon dilakukan oleh negara (hak menguasai negara). Namun, jika dilihat pada kepemilikan, karbon belum jelas apakah sebagai objek terpisah atau merupakan suatu kesatuan dari pepohonan, ataupun karbon merupakan sumber daya yang tidak dapat 'dihaki' seperti udara di angkasa.

\footnotetext{
${ }^{54}$ Frieda Husni Hasabullah, 2002, Hukum Kebendaan Perdata, Hil-Co, Jakarta Selatan,hlm 28
} 
Status CER sebagai bukti objek transaksi telah memenuhi syarat yaitu penguasaan manusia, memiliki manfaat bagi kehidupan manusia, dan memiliki kejelasan objek hukum sebagai basis hubungan subyek hukum. Karbon dapat dikuasai manusia berdasarkan hak kepemilikan karbon. Karbon dijadikan sebagai objek dalam perjanjian ERPA. Karbon memiliki nilai karena karbon telah mengalami komodifikasi. Karbon memiliki kemiripan karakteristik dengan komoditas pada umumnya, maka karbon dapat dikatakan sebagai sebuah komoditas yang dapat diperjual-belikan dalam mekanisme pasar dalam bentuk sebuah bukti transaksi.

\section{DAFTAR PUSTAKA}

Cifor. 2015. Apa sebenarnya hak karbon itu? Dalam https://forestsnews.cifor.org/28522/apa-sebenarnya-hak-karbon-itu?fnl=id diakses terakhir Tanggal 10 Februari 2019

Cifor. 2003. Warta Kebijakan Perdagangan Karbon. No. 8 Dalam www.cifor.org diakses terakhir Tanggal 15 Maret 2019

Danang Kuncara Sakti, 2005, Program Pascasarjana Universitas Indonesia, Dampak Protokol Kyoto Melalui Clean Development Mechanism Pada Sektor Kehutanan Terhadap Perekonomian Indonesia Sistem Neraca Sosial Ekonomi

Erna Mieke Naibaho, 2011. Tinjauan Hukum Dalam Perdagangan Kredit karbon. Tesis S-2 Fakultas Hukum, Univesitas Indonesia, Jakarta.

Hasabullah, Frieda Husni. 2002. Hukum Kebendaan Perdata. Jakarta Selatan: Hil-Co

Hindarto, Dicky Edwin. Andi Samyanugraha dan Debi Nathalia, 2018. Pasar Karbon: Pengantar Pasar Karbon untuk Perubahan Iklim. Jakarta: PMR Indonesia

Khan, Mizan R. 2014. Toward a Binding Climate Cange Adaptation Regime: A Proposed Framework. United Kingdom: Florence Production Ltd

Laurens Bakker dan Yanti Fristikawati (ed). 2014. Permasalahan kehutanan di Indonesia dan kaitannya dengan perubahan iklim serta REDD+. Yogyakarta: Pohon Cahaya

Marzuki, Peter Mahmud. 2008. Pengantar Ilmu Hukum Edisi Revisi. Jakarta: Kencana Prenadamedia Group

Mertokusumo, Sudikno. 2012. Teori Hukum. Gudang Penerbit. Jakarta

OECD, Emission Trading System, available at: https://www.oecd.org/environment/toolsevaluation/emissiontradingsystems.htm, last accesed July 8, 2020

Quirico, Ottavio dan Mouloud Boumghar. Climate Changes and Human Rights an International Comparative Law Perspective. New York: Routledge

Rahmadi, Takdir. 2013. Hukum Lingkungan di Indonesia. Jakarta: Rajawali Pers

Samyanugraha, Andi dan Debi Nathalia. 2018, Sistem Perdagangan Emisi: Pengantar Perancangan Dan Implementasi. Jakarta: PMR Indonesia.

Sanusi, Mujibussalim, Fikri, Perdagangan Karbon Hutan Aceh: Analisis Hukum Pada Tahapan Perencanaan, No.59 Th.XV (April, 2013) 
Stein, Bernadinus dalam Laurens Bakker dan Yanti Fristikawati (ed). 2014. Permasalahan kehutanan di Indonesia dan kaitannya dengan perubahan iklim serta REDD+. Yogyakarta: Pohon Cahaya

Stone, Susan. Mario Chacón León dan Patricia Fredericks. 2010. Perubahan Iklim dan Peran Hutan. Jakarta: Conservation International

United Nations Climate Change, Emissions Trading, Greenhouse gas emissions a new commodity, available at: https://unfccc.int/process/the-kyotoprotocol/mechanisms/emissions-trading, last accesed July 8, 2020

United Nations Climate Change, What is the Paris Agreement? Available at: https://unfccc.int/process-and-meetings/the-paris-agreement/what-is-the-parisagreement, last accesed July 8, 2020

Supardi. 2008. Hukum Lingkungan di Indonesia. Jakarta: Sinar Grafika Usman, Rachmadi. 2013. Hukum Kebendaa. Jakarta: Sinar Grafika . 2013. Mari Berdagang Karbon: Pengantar Pasar Karbon Untuk Pengendalian Perubahan Iklim. Jakarta: Dewan Nasional Perubahan Iklim . 2018. Pengantar Pasar Karbon untuk Pengendalian Perubahan Iklim. Jakarta Pusat: PMR Indonesia

\section{Peraturan Perundang-undangan}

1. Kitab Undang-Undang Hukum Perdata;

2. Undang-Undang Nomor 41 Tahun 1999 tentang Kehutanan (Lembar Negara Republik Indonesia Tahun 1999 Nomor 167, Tambahan Lembar Negara Nomor 3888);

3. Undang-Undang Nomor 6 Tahun 1994 tentang Pengesahan United Nations Framework Convention on Climate Change (Konvensi Kerangka Kerja Perserikatan Bangsa-Bangsa tentang Perubahan Iklim) (Lembaran Negara Republik Indonesia Tahun 1994 Nomor 42, Tambahan Lembaran Negara Nomor 3557);

4. Undang-Undang Nomor 17 Tahun 2004 tentang Ratifikasi Protokol Kyoto (Lembar Negara Republik Indonesia Tahun 2004 Nomor 72, Tambahan Lembar Negara Nomor 4403);

5. Peraturan Pemerintah Nomor 6 tahun 2007 tentang Tata Hutan dan Penyusunan Rencana Pengelolaan Hutan serta Pemanfaatan Hutan (Lembar Negara Republik Indonesia Tahun 2007 Nomor 22, Tambahan Lembar Negara Nomor 4696);

6. Peraturan Pemerintah Nomor 3 Tahun 2008 tentang perubahan PP Nomor 6 Tahun 2007 tentang Tata Hutan dan Penyusunan Rencana Pengelolaan Hutan serta Pemanfaatan Hutan (Lembar Negara Republik Indonesia Tahun 2008 Nomor 16, Tambahan Lembar Negara Nomor 4814);

7. Peraturan Menteri Kehutanan Nomor 68 Tahun 2008 tentang Penyelenggaraan Demonstration Activities Pengurangan Emisi Karbon Dari Deforestasi Dan Degradasi Hutan (Berita Negara Republik Indonesia Tahun 2008 Nomor 94); 
ISSN (Print): 2085-8477; ISSN (Online): 2655-4348

8. Peraturan Menteri Kehutanan Nomor 36 Tahun 2009 tentang Tata Cara Perizinan Usaha Pemanfaatan Penyerapan Dan/Atau Penyimpanan Karbon Pada Hutan Produksi Dan Hutan Lindung (Berita Negara Republik Indonesia Tahun 2009 Nomor 128) sebagaimana telah diubah dengan Peraturan Menteri Kehutanan Nomor P.11/MenhutII/2013 (Berita Negara Republik Indonesia Tahun 2013 Nomor 259);

9. Peraturan Menteri Kehutanan 20 Tahun 2012 tentang Penyelenggaraan Karbon Hutan (Berita Negara Republik Indonesia Tahun 2012 Nomor 458);

10. Peraturan Menteri Kehutanan Nomor 50 Tahun 2014 tentang Perdagangan Sertifikat Penurunan Emisi Karbon Hutan Indonesia atau Indonesia Certified Emission Reduction (Berita Negara Republik Indonesia Tahun 2014 Nomor 98 